\title{
ANALISIS RASIO KEUANGAN UNTUK MENGUKUR KINERJA KEUANGAN KOPERASI SERBA USAHA
}

\author{
${ }^{1}$ Sayekti Suindyah Dwiningwarni \\ Universitas Darul 'Ulum Jombang \\ Email : sayekti.fps@undar.ac.id \\ ${ }^{2}$ Ririn Dwi Jayanti \\ Universitas Darul 'Ulum Jombang \\ Email : ririn_dj@gmail.com
}

\begin{abstract}
The motivation of this research is the research of Dwiningwarni et.al (2019) and Shobihin et.al (2019). The research objective is to analyze the Cooperative's financial performance by using Financial Ratio and analysis financial statements. The analytical method used is the comparative method of Financial Ratios, Trend analysis and Common Size. The sampling technique uses systematic sampling. The results showed that 1) From the calculation of the ratio analysis used, the third ratio analysis, namely Liquidity, Profitability, Solvency and Activity showed an unfavorable condition. 2) From the Trend analysis shows that the trend tends to fluctuate up or down. 3) From the Common Size analysis, it shows that the items of assets, liabilities and capital provide figures that are less comparable or can be said to be unhealthy, because the amount of liabilities is greater than assets and capital. This means it can be concluded that the Cooperative's financial condition is not healthy, so there needs to be improved management or management. Improved management not only from the financial side but also from the HR side. One of the causes of unhealthy cooperative financial performance is liquidity ratios, solvency, profitability and activities that show poor and not good results.
\end{abstract}

Keywords: Financial Ratio Analysis, Trend Analysis, Common Size

\begin{abstract}
ABSTRAK
Motivasi dari penelitian ini adalah penelitian Dwiningwarni et.al (2019) dan Shobihin et.al (2019). Tujuan penelitian adalah untuk menganalisis kinerja keuangan Koperasi dengan menggunakan analisis Rasio Keuangan dan laporan keuangan. Metode analisis yang digunakan adalah metode perbandingan Rasio Keuangan, analisis Trend dan Common Size. Teknik pengambilan sampel menggunanakan sistematis sampling. Hasil penelitian menunjukkan bahwa 1) Dari hasil perhitungan analisis rasio yang digunakan, maka ketiga analisis rasio, yaitu Likuiditas, Profitabilitas, Solvabilitas dan Aktifitas menunjukkan suatu kondisi yang kurang baik. 2) Dari analisis Trend menunjukkan bahwa trend cenderung mengalami fluktuasi naik atau turun. 3) Dari analisis Common Size menunjukkan bahwa pos-pos aktiva, kewajiban dan modal memberikan angka kurang sebanding atau dapat dikatakan tidak sehat, karena jumlah kewajiban lebih besar dari asset dan modal. Ini berarti dapat disimpulkan bahwa kondisi keuangan Koperasi kurang sehat, sehingga perlu adanya perbaikan pengelolaan atau manajemen. Perbaikan pengelolaan tidak hanya dari sisi keuangan tetapi juga dari sisi SDM. Salah satu penyebab kinerja keuangan koperasi kurang sehat adalah dari rasio likuiditas, solvabilitas, profitabilitas dan aktifitas menunjukkan hasil yang Kurang Baik dan Tidak Baik.
\end{abstract}

Kata kunci : Analisis Rasio Keuangan, Analisis Trend, Common Size

\section{PENDAHULUAN}

Kinerja keuangan adalah sesuatu yang dilakukan untuk melihat sejauh mana suatu perusahaan atau badan telah melaksanakan dengan menggunakan aturan-aturan pelaksanaan keuangan secara baik dan benar (Fahmi, 2014). Dengan menilai kinerja J-MACC : Journal of Management and Accounting 
keuangan Koperasi Serba Usaha Mega Mas dapat diketahui tentang analisis laporan keuangan dalam tingkat keberhasilan koperasi dalam melakukan usahannya.

Analisis rasio keuangan (ratio analysis) merupakan salah satu alat analisis keuangan yang paling populer dan banyak digunakan didalam koperasi maupun perusahaan lainnya. Ada beberapa alat penting menurut analisis rasio menggunakan metode analisis rasio likuiditas yaitu analisis yang mengevaluasi kemampuan jangka pendek, solvabilitas yaitu analisis untuk menilai kemampuan memenuhi kewajiban jangka panjang, profitabilitas (rentabilitas) yaitu untuk menghasilkan keuntungan dan aktivitas yaitu analisis yang dilakukan perusahaan menjalankan operasinnya baik dalam kegiatan apapun. Melalui laporan keuangan dapat diperoleh informasi yang menyangkut posisi keuangan dan perubahannya sekaligus mencerminkan kinerja keuangan (Fatmawati, 2012). Koperasi berperan penting dalam membangun dan mengembangkan perekonomian rakyat. Tujuan didirikan koperasi adalah membantu masyarakat agar kehidupannya sejahtera, adil dan makmur. Koperasi adalah lembaga yang berdasarkan atas asas kekeluargaan. Dalam mencapai keberhasilan koperasi perlu dukungan anggota dan pengurus koperasi. Keberhasilan koperasi tersebut diukur dengan kinerja keuangan (Maria, 2015).

Permasalahan dalam penelitian ini adalah bagaimana mengukur kinerja keuangan koperasi dengan menggunakan analisis rasio dan laporan keuangan. Karena koperasi merupakan soko guru pembangunan di Indonesia, maka koperasi perlu untuk dikembangkan. Penelitian ini juga dilakukan dengan alasan bahwa di Indonesia, jumlah koperasi banyak, namun masih sedikit koperasi yang berkembang sesuai dengan moto Koperasi, yaitu "Soko Guru Ekonomi".

\section{LANDASAN TEORI}

\section{Rasio Keuangan}

Rasio keuangan adalah perbandingan jumlah, dari satu jumlah dengan jumlah lainnya (Fahmi, 2014). Rasio keuangan adalah angka yang diperoleh dari hasil perbandingan dari suatu pos laporan keuangan dan pos lainnya yang mempunyai hubungan yang relevan dan signifikan (Harahap, 2009). Rasio keuangan adalah sesuatu yang mengambarkan tentang suatu jumlah dengan jumlah yang lain (Hendry, 2013). 
Dari beberapa definisi tentang rasio keuangan dapat disimpulkan bahwa yang disebut rasio keuangan adalah perbandingan dari suatu pos dengan pos lainnya dalam laporan keuangan yang memiliki hubungan yang relevan untuk mengukur kemampuan dan kesehatan perusahaan/lembaga.

Analisis Rasio Keuangan adalah salah satu alat analisis keuangan yang paling popular di gunakan (Subramanyam, KR dan John, J. Wild, 2010). Analisis rasio keuangan yang digunakan dalam penelitian ini adalah (Fahmi, 2014).:

1. Rasio Likuiditas, yaitu suatu rasio yang digunakan untuk mengukur kemampuan perusahaan dalam membayar hutang-hutangnya baik jangka pendek.

2. Rasio Profitabilitas, adalah suatu rasio yang digunakan untuk mengukur kemampuan perusahaan dalam mengumpulkan keuntungan dalam satu periode tertentu.

3. Rasio Solvabilitas, yaitu rasio yang digunakan perusahaan untuk mengukur kemampuan perusahaan dalam membiayai kegiatan/operasional yang berasal dari hutang.

4. Rasio Aktivitas, yaitu rasio yang digunakan untuk mengukur kemampuan perusahaan dalam menjalankan aktivitas operasional perusahaan dalam segala bentuk.

\section{Macam-Macam Rasio Keuangan}

\section{A. Rasio Likuiditas}

Rasio Likuiditas ini terdiri dari:

\section{Rasio Lancar (Current Ratio)}

Rasio lancar ini menunjukkan sejauh mana aset lancar menutupi dengan hutang lancar. Semakin besar perbandingan aset lancar dengan hutang lancar semakin tinggi kemampuan perusahaan menutupinya. Rasio lancar menunjukkan aset lancar dibagi hutang lancar dan dikalikan seratus persen (Munawir, 2012).

$$
\text { Curret Ratio }=\frac{\text { Aset Lancar }}{\text { Hutang Lancar }} \times 100 \%
$$

\section{Rasio Cepat (Quick Ratio)}

Rasio singkat dihitung dengan cara mengurangi persediaan (inventory) dari aset dan membagi sisanya dengan hutang lancar. Persediaan merupakan aset lancar yang paling rendah tingkat likuiditasnya dan merupakan aset yang paling mungkin menimbulkan kerugian bila koperasi dilikuidasi. Jadi rasio ini merupakan ukuran kemampuan koperasi memenuhi kewajiban jangka 
pendeknya tanpa mengandalkan pada persediaan, karena persediaan memerlukan waktu yang relatif lama untuk direalisir menjadi uang kas. Rasio ini lebih tajam daripada current ratio karena hanya membandingkan aset yang sangat likuid (mudah dicairkanatau diuangkan) dengan hutang lancar (Fahmi, 2014).

$$
\text { Quick Ratio }=\frac{\text { Aset Lancar-Persediaan }}{\text { Hutang Lancar }} \times 100 \%
$$

\section{Rasio Kas (Cash Ratio)}

Rasio kas digunakan untuk mengukur kemampuan aset yang akan direalisir dalam memenuhi kewajiban jangka pendek milik koperasi. Rasio ini menggambarkan seberapa jauh kemampuan kas dalam menjamin hutang lancarnya (Munawir, 2012).

$$
\text { Cash Ratio }=\frac{\text { Kas }}{\text { Hutang Lancar }} \times 100 \%
$$

\section{B. Rasio Profitabilitas}

\section{Rasio Profitabilitas terdiri dari:}

1. Rasio Pengembalian Investasi (Return on Investement)

Rasi yang menunjukkan semakin tinggi rasio ini semakin baik keadaan suatu perusahaan. Return on investment merupakan rasio yang menujukkan berapa besar laba bersih diperoleh perusahaan bila diukur dari nilai aset (Harahap, 2009).

$$
\text { Return on Investement }=\frac{\text { EBIT }(\text { Laba bersih before pajak })}{\text { Total Aset }} \times 100 \%
$$

2. Tingkat Pengembalian Ekuitas (Return on Equity)

Rasio ini merupakan perbandingan antara laba setelah pajak dengan ekuitas (modal sendiri). Ekuitas adalah kemampuan suatu perusahaan dengan ekuitas yang bekerja untuk menghasilkan keuntungan (Harahap, 2009)

$$
\text { Return on Equity }=\frac{\text { EAT }}{\text { Ekuitas }} \times 100 \%
$$

\section{Rasio Solvabilitas}

Rasio ini terdiri dari:

1. Rasio Hutang dengan Asset (Total Debt to Asset Ratio)

Rasio ini menekankan pentingnya pendanaan hutang dengan jalan menunjukkan persentase aktiva perusahaan yang didukung oleh pendanaan hutang. Rasio ini menunjukkan sampai mana hutang-hutang perusahaan dapat ditutupi oleh aktiva. 
Semakin tinggi rasio semakin besar resiko keuangan dan demikian pada sebaliknya (Munawir, 2012:)

Total Debt to Asset Ratio $=\frac{\text { Total Hutang }}{\text { Total Asset }} \times 100 \%$

\section{Rasio Hutang terhadap Ekuitas (Total Debt to Equity Ratio}

Rasio ini menujukkan sejauh mana hutang tersebut telah ditutupi dengan ekuitas pemegang saham. Rasio ini menunjukkan semakin kecil hutangnya maka semakin baik untuk keamanan pihak luar, jika jumlah modal lebih besar dari jumlah hutang atau minimal sama (Harahap, 2009)

Total Debt to Equity Ratio $=\frac{\text { Total Hutang }}{\text { Ekuitas }}$ x $100 \%$

\section{Rasio Aktivitas}

Rasio ini terdiri dari:

\section{Perputaran Persediaan (Inventory Turnover)}

Rasio ini merupakan perbandingan antara harga pokok penjualan dengan rata-rata persediaan. Semakin besar rasio ini semakin baik karena dianggap bahwa kegiatan penjualan berjalan cepat (Harahap, 2009).

$$
\text { Perputaran Persediaan }=\frac{\text { HPP }}{\text { Rata }- \text { rata Persediaan }}
$$

\section{Rata-Rata Pengumpulan Piutang (Day's Sales Outstanding)}

Rasio ini merupakan perbandingan antara piutang dengan penjualan dibagi jumlah hari dalam setahun. Semakin piutang lebih dari 60 hari maka perusahaan kurang baik sehingga tidak mampu menangih pada saat itu atau perusahaan telah memberikan syarat kredit yang telalu lunak (Munawir, 2012).

$$
\text { Rata-Rata Pengumpulan Piutang }=\frac{\text { Piutang }}{\text { Penjualan } / 360 \text { hari }}
$$

\section{Perputaran Total Aset (Total Asset Turnover)}

Rasio ini merupakan perbandingan antara penjualan dengan total aset. Semakin besar rasio ini semakin baik karena perusahaan dianggap efektif dalam mengelola asetnya (Harahap, 2009)

$$
\text { Perputaran Total Aset }=\frac{\text { Penjualan }}{\text { Total Aset }}
$$

\section{Kinerja Keuangan}

Kinerja Keuangan adalah kondisi suatu perusahaan yang dapat menujukkan seberapa mampu menghasilkan keuntungan dan kemakmuran kepada para pemegang 
saham (Adha, W., Rahmawati, V., dan Al Azhar, A, 2014). Kinerja Keuangan adalah suatu analisis yang dilakukan untuk melihat sejauh mana suatu perusahaan telah melaksanakan kegiatan dengan menggunakan aturan-aturan pelaksanaan keuangan secara baik dan benar (Fahmi, 2014). Dari beberapa definisi tentang kinerja keuangan dapat diambil perumusan bahwa yang disebut dengan kinerja keuangan adalah kemampuan perusahaan dalam menghasilkan keuntungan dan kemakmuran para pemegang saham dalam suatu periode waktu tertentu.

\section{Laporan Keuangan}

Laporan keuangan merupakan suatu informasi yang menggambarkan kondisi perusahaan, dimana selanjutnya akan menjadi informasi tentang kinerja suatu perusahaan (Fahmi, 2014). Laporan keuangan merupakan informasi yang diharapkan mampu memberikan bantuan kepada pengguna untuk membuat keputusan ekonomi yang bersifat finansial (Farid dan Siswanto, 2011). Laporan keuangan merupakan alat yang sangat penting untuk memperoleh informasi sehubungan posisi keuangan dan hasil-hasil yang telah dicapai oleh perusahaan yang bersangkutan (Munawir, 2012). Laporan keuangan menggambarkan kondisi keuangan dan hasil usaha suatu perusahaan pada saat tertentu tau jangka waktu tertentu (Harahap, 2009).

Manfaat laporan keuangan bagi koperasi (IAI, 2009) antara lain : 1) mengetahui manfaat yang diperoleh dengan menjadi anggota koperasi. 2) mMengetahui prestasi keuangan koperasi selama satu periode dengan sisa hasil usaha dan manfaat keanggotaan koperasi sebagai ukuran. 3) mengetahui sumber daya ekonomis yang dimiliki koperasi, kewajiban dan kekayaan bersih dengan pemisahan antara yang berkaitan dengan anggota dan bukan anggotanya. 4) mengetahui transaksi, kejadian dan keadaan yang menguba sumber daya ekonomis, kewajiban dan kekayaan bersih dalam satu periode dengan pemisahan antara yang berkaitan dengan anggota dan bukan anggota. 5) mengetahui informasi penting lainnya yang mungkin mempengaruhi likuiditas dan solvabilitas koperasi. 


\section{Kerangka Berpikir}

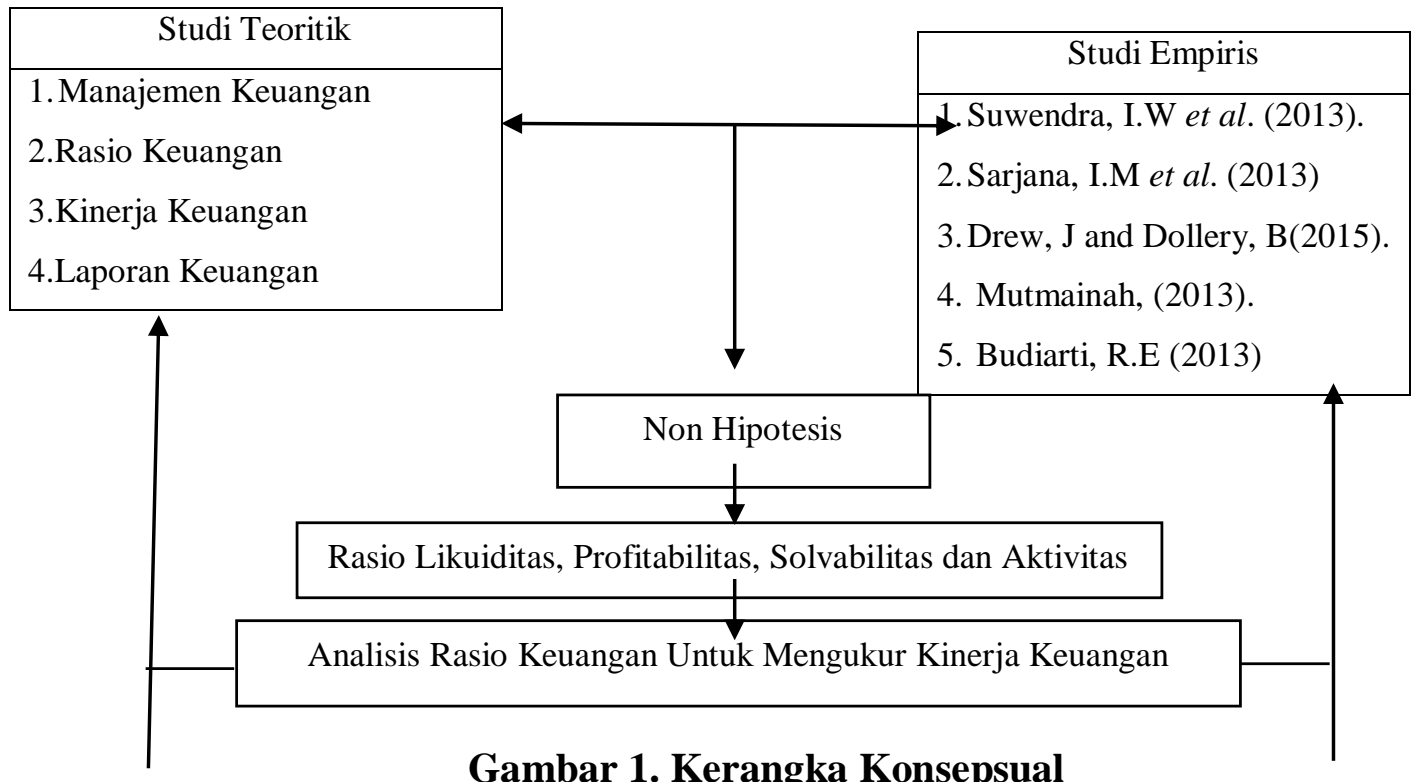

Gambar 1. Kerangka Konsepsual

\section{METODE PENELITIAN}

\section{Pendekatan Penelitian}

Penelitian ini menggunakan pendekatan longitudinal, yaitu sebuah model pendekatan yang dilakukan dengan some-shoot method terhadap kasus yang sama. Pendekatan ini digunakan karena data yang digunakan adalah data sekunder yang berasal dari laporan keuangan perusahaan/lembaga yang berbentuk Koperasi.

\section{Objek dan Subjek Penelitian}

Objek penelitian ini berupa data laporan keuangan perusahaan selama tahun 20112015. Sedangkan subjek penelitian ini adalah pegawai bagian keuangan.

\section{Teknik Pengumpulan Data}

Pengumpulan data dalam penelitian ini dilakukan dengan cara: 1) wawancara, dan 2) Dokumentasi. Wawancara dilakukan kepada pimpinan Koperasi dan karyawan/pegawai bagian keuangan. Dokumen yang dibutuhkan dalam penelitian ini adalah Laporan Keuangan (2011-2015).

\section{Teknik Analisis Data}

Analisis data dilakukan dengan menggunakan:

1. Analisis Rasio, yang berupa:

a. Likuiditas

b. Profitabilitas 
c. Solvabilitas

d. Aktifitas

2. Analisis Trend, dengan menggunakan grafis.

Analisis trend yang digunakan, antara lain:

- Trend Rasio Lancar (Current Ratio)

- Trend Rasio cepat (Quick Ratio)

- Trend Rasio Kas (Cash Ratio)

- Trend Rasio Hutang dengan Aktiva (Total Debt to Asset ratio)

- Trend Rasio Hutang terhadap Ekuitas (Total Debt to Asset ratio)

- Trend Rasio Pengembalian Investasi (Return on Investement)

- Trend Rasio Pengembalian Ekuitas (Return on Equity)

- Trend Rasio Perputaran Persediaan (Inventory Turnover)

- Trend Rasio Rata-Rata Pengumpulan Piutang (Day's Sales Outstanding)

- Tren Rasio Perputaran Total Aset (Total Asset Turnover)

3. Analisis Common Size

\section{PEMBAHASAN}

\section{Analisis Rasio}

Hasil perhitungan analisis ratio yang digunakan dalam penelitian ini tampak pada Tabel 1 berikut:

Tabel 1 Hasil Perhitungan Analisis Rasio

\begin{tabular}{|c|c|c|c|c|c|c|c|}
\hline $\begin{array}{c}\text { Rasio } \\
\text { Keuangan }\end{array}$ & 2011 & 2012 & 2013 & 2014 & 2015 & Rata-Rata & Nilai \\
\hline \multicolumn{8}{|l|}{ Likuiditas } \\
\hline Current Ratio & $136,50 \%(\mathrm{~B})$ & $147,58 \%(\mathrm{~B})$ & $152,54 \%(\mathrm{~B})$ & $151,32 \%(\mathrm{~B})$ & $151,32 \%(\mathrm{~B})$ & $147,85 \%(\mathrm{~B})$ & 25 \\
\hline Quick Ratio & $131,51 \%(\mathrm{~B})$ & $141,81 \%(\mathrm{~B})$ & $\begin{array}{r}149,98 \% \\
\text { (B) }\end{array}$ & $148,76 \%(\mathrm{~B})$ & $149,67 \%$ (B) & $144,34 \%$ (B) & 25 \\
\hline Cash Ratio & $2,74 \%(\mathrm{~TB})$ & $2,73 \%(\mathrm{~TB})$ & $1,23 \%(\mathrm{~TB})$ & $0,13 \%(\mathrm{~TB})$ & $0,13 \%(\mathrm{~TB})$ & $1,39 \%(\mathrm{~TB})$ & 0 \\
\hline \multicolumn{8}{|l|}{ Solvabilitas } \\
\hline $\begin{array}{l}\text { Total Debt to } \\
\text { Equity ratio }\end{array}$ & $142,10 \%(\mathrm{~B})$ & $152,13 \%(\mathrm{~B})$ & $155,10 \%(\mathrm{~B})$ & $153,89 \%(\mathrm{~B})$ & $153,89 \%(\mathrm{~B})$ & $151.42 \%(\mathrm{~B})$ & 75 \\
\hline $\begin{array}{c}\text { Total Debt to } \\
\text { Asset ratio }\end{array}$ & $245,98 \%$ (B) & $191,80 \%$ (B) & $181,96 \%$ (B) & $294,97 \%$ (B) & $294,97 \%$ (B) & $241,87 \%$ (B) & 75 \\
\hline \multicolumn{8}{|l|}{ Profitabilitas } \\
\hline ROI & $0,50 \%(\mathrm{~TB})$ & $0,50 \%$ (TB) & $0,39 \%$ (TB) & $0,28 \%$ (TB) & $0,28 \%$ (TB) & $0,42 \%(\mathrm{~TB})$ & 0 \\
\hline ROE & $1,70 \%(\mathrm{~TB})$ & $1,42 \%$ (TB) & $0,98 \%$ (TB) & $0,71 \%(\mathrm{~TB})$ & $0,71 \%$ (TB) & $1,10 \%$ (TB) & 0 \\
\hline \multicolumn{8}{|l|}{ Aktivitas } \\
\hline $\begin{array}{l}\text { Perputaran } \\
\text { Persediaan }\end{array}$ & $2,06 \%(\mathrm{~TB})$ & $2 \%(\mathrm{~TB})$ & $2,05 \%(\mathrm{~TB})$ & $2,73 \%(\mathrm{~TB})$ & 2,73 (TB) & $2,17 \%(\mathrm{~TB})$ & 0 \\
\hline $\begin{array}{c}\text { Rata-rata } \\
\text { periode } \\
\text { Pengumpulan } \\
\text { Piutang }\end{array}$ & 30 & 36 & 42 & 39 & 39 & $37,2 \%(\mathrm{~TB})$ & 0 \\
\hline $\begin{array}{l}\text { Perputaran } \\
\text { Total Aset }\end{array}$ & $1,01 \%(\mathrm{~TB})$ & $1,05 \%(\mathrm{~TB})$ & $0,80 \%$ (TB) & $0,88 \%(\mathrm{~TB})$ & $0,88 \%$ (TB) & $0,92 \%(\mathrm{~TB})$ & 0 \\
\hline
\end{tabular}

Sumber: Data diolah, 2017 
Keterangan :

- B : Baik

- KB : Kurang Baik

- $\mathrm{TB} \quad$ : Tidak Baik

Tabel 1 menunjukkan bahwa hasil perhitungan analisis likuiditas, yang berupa Current Ratio dari tahun 2011 sampai dengan tahun 2015 memberikan angka yang naik, namun jika dibandingkan per tahun, maka akan tampak bahwa tahun 2011 ke tahun 2012 mengalami kenaikan walaupun masih masuk dalam kriteria Baik (KB). Ini disebabkan karena jumlah asset lancar yang digunakan untuk membayar kewajiban lancar kurang mencukupi. Tahun 2012 ke tahun 2013, mengalami kenaikan dengan angka 152,54\%, angka ini menunjukkan bahwa kondisi keuangan perusahaan adalah lancar (dalam krietria Baik). Tahun 2013 ke tahun 2014, mengalami penurunan dengan angka $151,32 \%$, angka ini menunjukkan bahwa kondisi keuangan perusahaan adalah lancar (dalam kriteria Baik). Tahun 2014-2015, mengalami penurunan dengan angka $151,32 \%$, angka ini menunjukkan bahwa keuangan perusahaan dalam kondisi lancar (dalam kriteria Baik). Dari nilai rata-rata selama lima tahun didapatkan angka sebesar 147, $85 \%$ dengan nilai 25 . Ini artinya bahwa kondisi likuiditas perusahaan dari tahun 2011 sampai dengan tahun 2015 dikatakan baik, karena nilai rata-rata yang diperolah dibawah $150 \%$ dan nilai perhitungan 25 . Hasil penelitian ini sesuai dengan penelitian Suwendra, I.W et.al. (2013), Sarjana et al. (2013), dan Budiarti (2013).

Perhitungan Quick Ratio menunjukkan bahwa dari tahun 2011 sampai dengan tahun 2015 mengalami kenaikan, yaitu dari 131,51\% (B) menjadi 149,67\% (B). Angka ini menunjukkan bahwa likuiditas perusahaan dari tahun 2011-2015 dikatakan baik. Artinya perusahaan dikatakan mampu memenuhi kewajibannya dengan asset lancar yang tersedia. Rata-rata hasil perhitungan Quick Ratio selama lima tahun menunjukkan angka $144,34 \%$ (B) dengan nilai rasio 25 . Ini berarti kondisi likuiditas koperasi dari tahun 2011-2015 dikatakan baik, karena nilai rasio diatas 20\%. Hasil penelitian ini sejalan dengan penelitian Suwendra, I.W et.al. (2013), Sarjana et al. (2013), dan Budiarti (2013).

Perhitungan Cash Ratio menunjukkan bahwa nilai rata-rata sebesar 1,39\% dan nilai rasio sebesar 0. Ini berarti bahwa secara tunai likuiditas koperasi dikatakan Tidak Baik karena nilai rata-rata rasio yang diperoleh di bawah 20\%. Kondisi ini tidak bisa 
dibiarkan terus, karena dalam jangka panjang, jika kondisi ini dibiarkan, maka Koperasi akan mengalami gulung tikar. Ini terjadi karena koperasi tidak mampu melunasi kewajibannya dengan menggunakan uang kas yang tersedia. Hasil penelitian ini tidak sejalan dengan penelitian Suwendra, I.W et.al. (2013), Sarjana et al. (2013), dan Budiarti, R.E (2013).

Perhitungan rasio profitabilitas menunjukkan bahwa kondisi ROI dari tahun 2011 2015 dikatakan tidak baik, karena memiliki angka rata-rata rasio sebesar 0,42\% atau dibawah 20\%. Ini berarti bahwa kondisi keuangan koperasi belum memenuhi kriteria sehat. Hasil penelitian ini tidak sejalan dengan penelitian Suwendra, I.W et.al. (2013), Sarjana et al. (2013), dan Budiarti (2013). Dari sisi ROE, dari tahun 2011 sampai dengan tahun 2015 diperoleh hasil rata-rata sebesar 1,10\%, angka ini menunjukkan kondisi rasio profitabilitas yang tidak baik (TB), karena nilai prosentase dibawah $20 \%$. Hasil penelitian ini tidak sejalan dengan penelitian Suwendra, I.W et.al. (2013), Sarjana et al. (2013), dan Budiarti, R.E (2013).

Perhitungan rasio solvabilitas menunjukkan bahwa kedua rasio yaitu TDER dan TADR menunjukkan hasil bahwa nilai rata-rata kedua rasio tersebut dari tahun 2011 sampai dengan tahun 2015 sebesar $151.42 \%$ untuk TDER dan $241,87 \%$ untuk TADR. Ini berarti bahwa nilai rasio kedua rasio tersebut di atas $20 \%$ dan ini masuk dalam kriteria baik. Hasil penelitian sejalan dengan penelitian Suwendra, I.W et.al. (2013), Sarjana et al. (2013), dan Budiarti, R.E (2013).

Perhitungan rasio aktivitas menunjukkan bahwa nilai rata-rata ketiga rasio (perputaran persediaan, rata-rata periode pengumpulan piutang, dan perputaran total aset) selama tahun 2011 - 2015 sebesar 2,17\% untuk perputaran persediaan, 37,2\% untuk rata-rata periode pengumpulan piutang dan $0,92 \%$ untuk perputaran total aset. Ini berarti bahwa nilai rasio dari ketiga rasio tersebut dibawah $20 \%$ yang berarti tidak baik. Hasil penelitian ini tidak sejalan dengan penelitian Suwendra, I.W et.al. (2013), Sarjana et al. (2013), dan Budiarti, R.E (2013).

\section{Analisis Trend}

Analisis trend yaitu suatu metode atau teknik untuk mengetahui tentang keadaan keuangan perusahaan yang menunjukkan perubahan tetap, naik atau bahkan turun dalam beberapa tahun sehingga dapat diketahui perkembagan keuangan perusahaan. Hasil perhitungan analisis trend, sebagai berikut: 


\section{Analisis Trend Rasio Lancar (Current Ratio)}

Hasil perhitungan analisis trend untuk rasio lancar tampak pada Gambar 2 berikut:

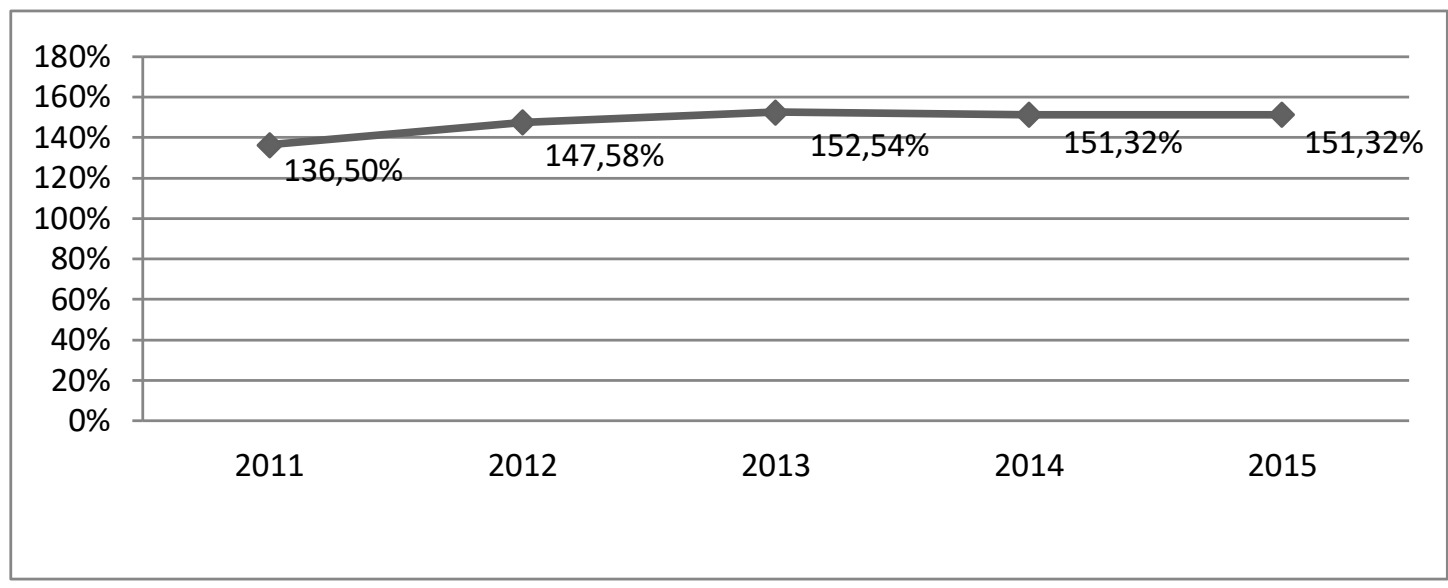

Gambar 2. Analisis Trend Rasio Lancar

Gambar 2 menunjukkan bahwa selama tahun 2011 - 2015 kecenderungan dari rasio lancar adalah menaik. Ini menunjukkan bahwa kondisi keuangan perusahaan/koperasi dalam kondisi baik. Kondisi ini sesuai dengan hasil perhitungan analisis rasio lancar yang menunjukkan hasil yang baik. Hasil penelitian ini sejalan dengan penelitian Mutmainnah, N dan Wardhani, R (2013).

\section{Analisis Trend Rasio Cepat (Quick Ratio)}

Hasil perhitungan analisis trend untuk rasio lancar tampak pada Gambar 3 berikut:

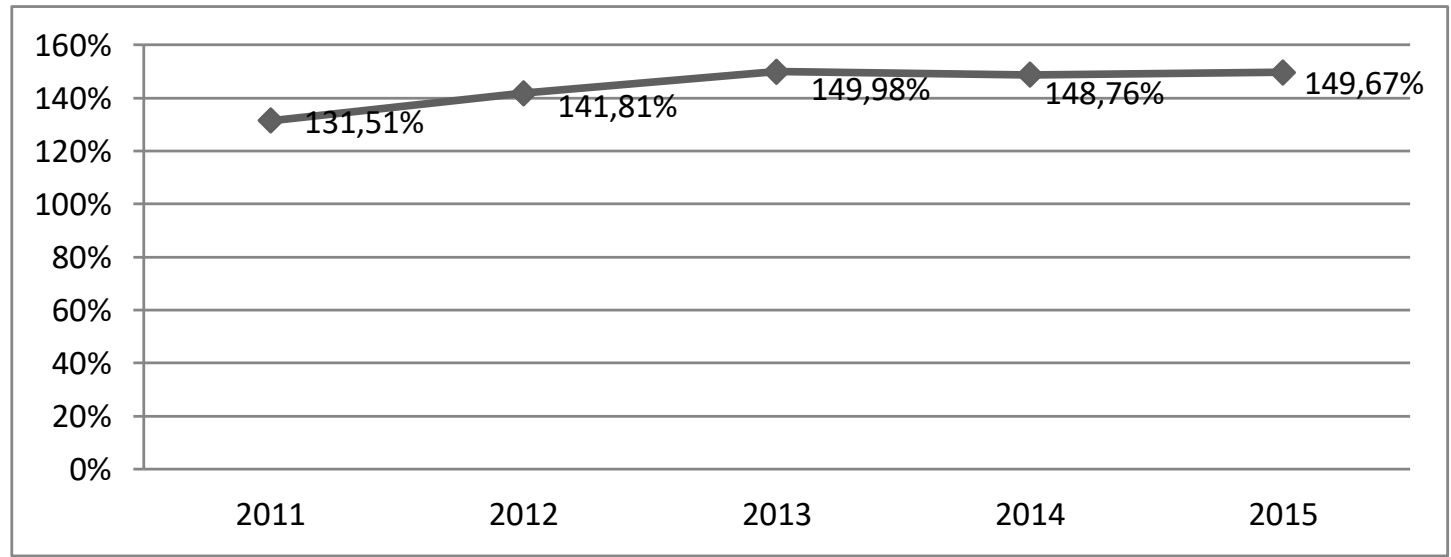

Gambar 3. Analisis Trend Rasio Cepat

Gambar 3 menunjukkan bahwa hasil analisis trend dari rasio cepat adalah menaik, ini berarti bahwa kondisi keuangan perusahaan/koperasi dari tahun 2011 - 2015 adalah 
dalam kondisi baik. Kondisi ini sesuai dengan hasil perhitungan analisis rasio. Hasil penelitian ini sesuai dengan penelitian Mutmainnah, N dan Wardhani, R (2013).

\section{Analisis Trend Rasio Kas (Cash Ratio)}

Hasil perhitungan analisis tren untuk analisis rasio kas tampak pada Gambar 4 berikut:

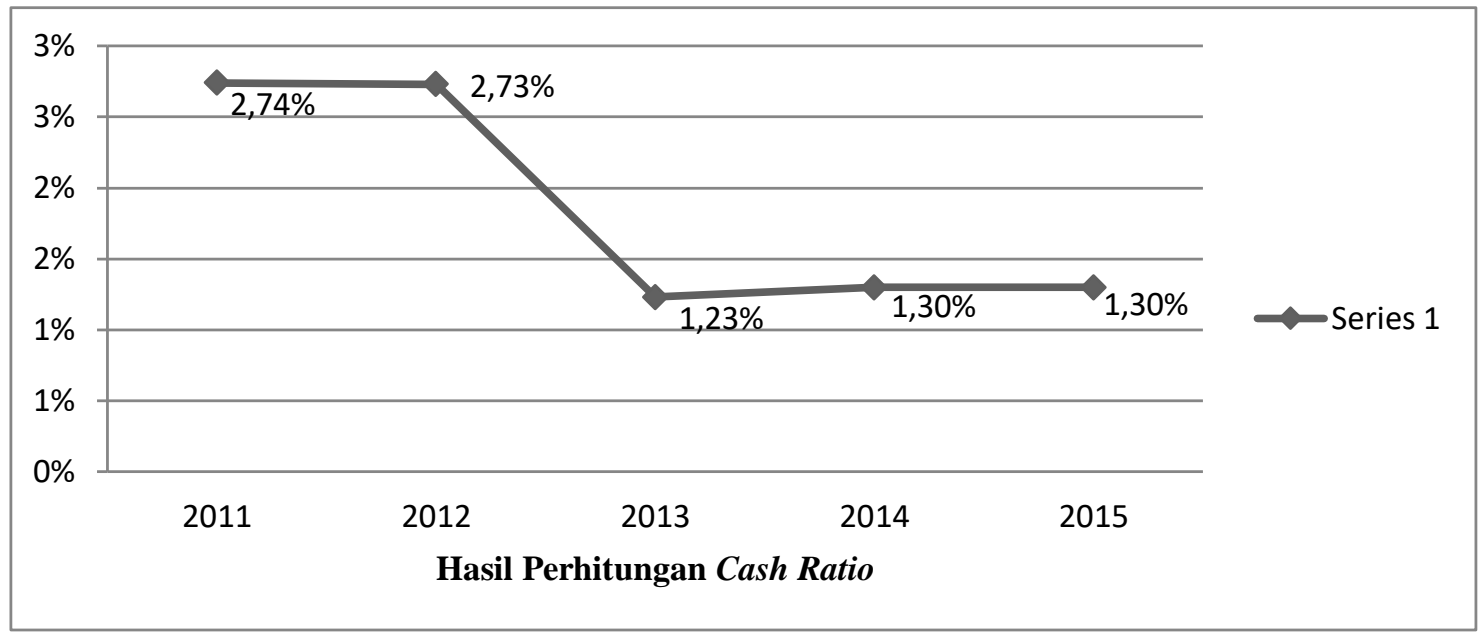

Gambar 4. Analisis Trend Rasio Kas

Gambar 4 menunjukkan bahwa dari tahun 2011-2015 tren untuk rasio kas mengalami penurunan, hal ini menunjukkan bahwa kemampuan perusahaan/koperasi dalam menghasilkan kas baik di bank atau di tangan masih kecil. Sehingga kondisi kesehatan koperasi dapat dikatakan tidak sehat. Hasil penelitian ini tidak sejalan dengan penelitian Mutmainnah, N dan Wardhani, R (2013).

\section{Analisis Trend Rasio Hutang terhadap Modal (Total debt to Equity ratio)}

Hasil perhitungan analisis trend untuk analisis rasio Hutang terhadap Modal tampak pada Gambar 5 berikut:

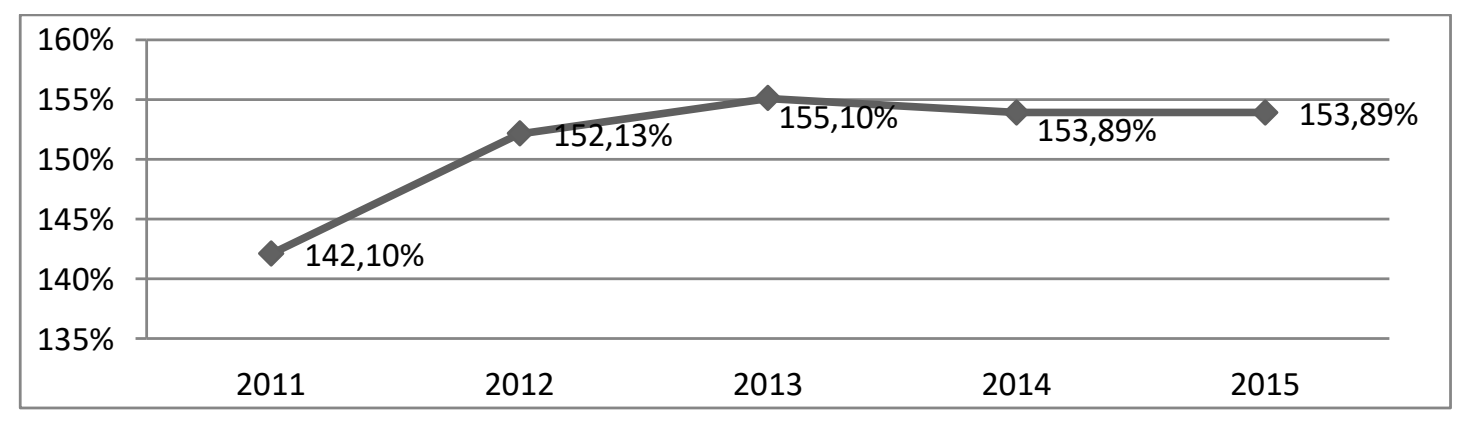

Gambar 5. Analisis Trend Rasio Total Hutang Terhadap Modal

Gambar 5 menunjukkan bahwa tren rasio Total Hutang terhadap Modal yang dimiliki koperasi menunjukkan kenaikan. Ini berarti bahwa perusahaan/koperasi mampu 
untuk membayar hutang-hutannya dengan modal sendiri yang dimiliki oleh koperasi. Hasil penelitian ini tidak sejalan dengan penelitian Mutmainnah, $\mathrm{N}$ dan Wardhani, $\mathrm{R}$ (2013).

\section{Analisis Trend Rasio Hutang terhadap Asset (Total Debt to Asset Ratio)}

Hasil perhitungan analisis tren untuk rasio Total Hutang terhadap Asset tampak pada Gambar 6 berikut:

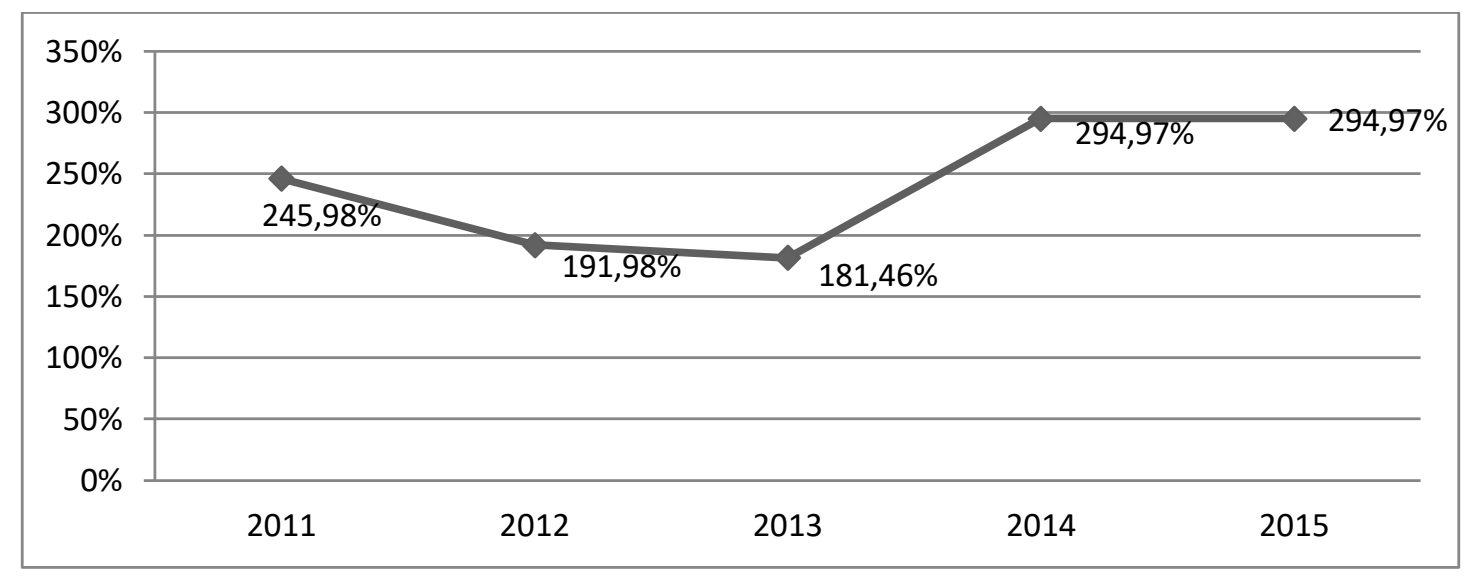

Gambar 6. Analisis Trend Rasio Hutang terhadap Asset

Gambar 6 menunjukkan bahwa tren untuk rasio hutang terhadap asset mengalami fluktuasi, yaitu turun dan naik. Ini menunjukkan bahwa kemampuan koperasi dalam memenuhi kewajiban jangka panjangnya belum lancar. Hasil penelitian ini sejalan dengan penelitian Mutmainnah, N dan Wardhani, R (2013).

\section{Analisis Trend Rasio Pengembalian Investasi (Return on Investement)}

Hasil perhitungan analisis tren untuk rasio pengembalian investasi tampak pada Gambar 7 berikut:

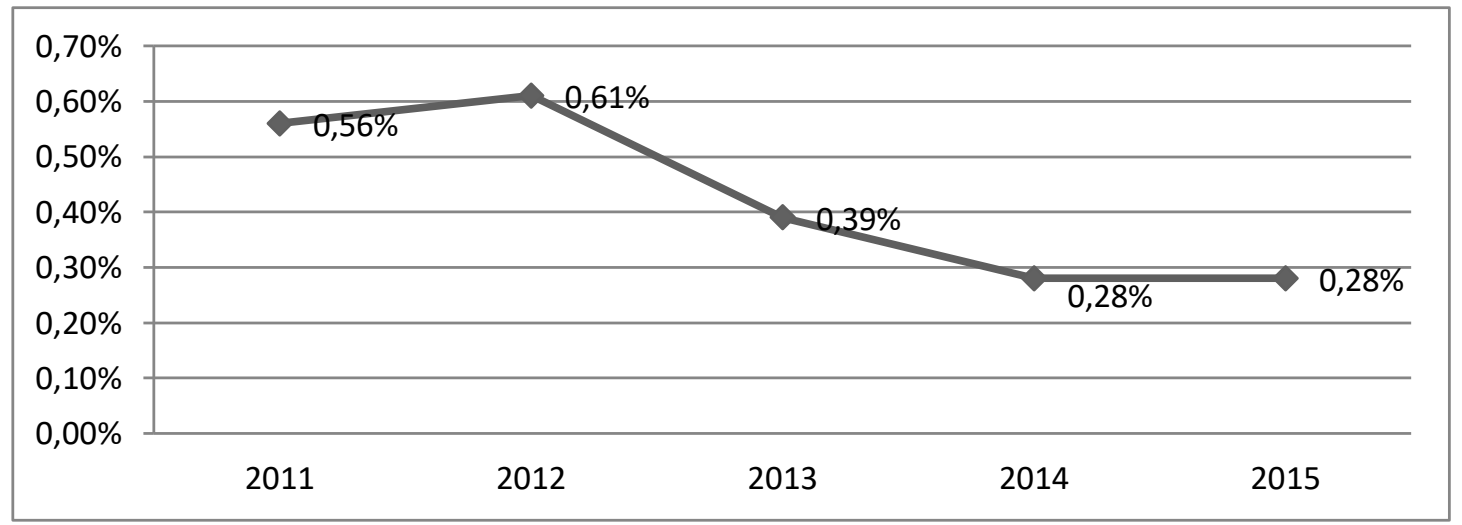

Gambar 7. Analisis Trend Rasio Perputaran Investasi

Gambar 7 menunjukkan bahwa tren dari rasio perputaran investasi mengalami penurunan. Ini berarti bahwa koperasi belum sanggup untuk membayar deviden para 
pemegang saham. Hasil penelitian ini sejalan dengan penelitian Mutmainnah, $\mathrm{N}$ dan Wardhani, R (2013).

\section{Analisis Trend Rasio Pengembalian Ekuitas (Return on Equity)}

Hasil perhitungan analisis tren untuk rasio pengembalian ekuitas tampak pada Gambar 8 berikut:

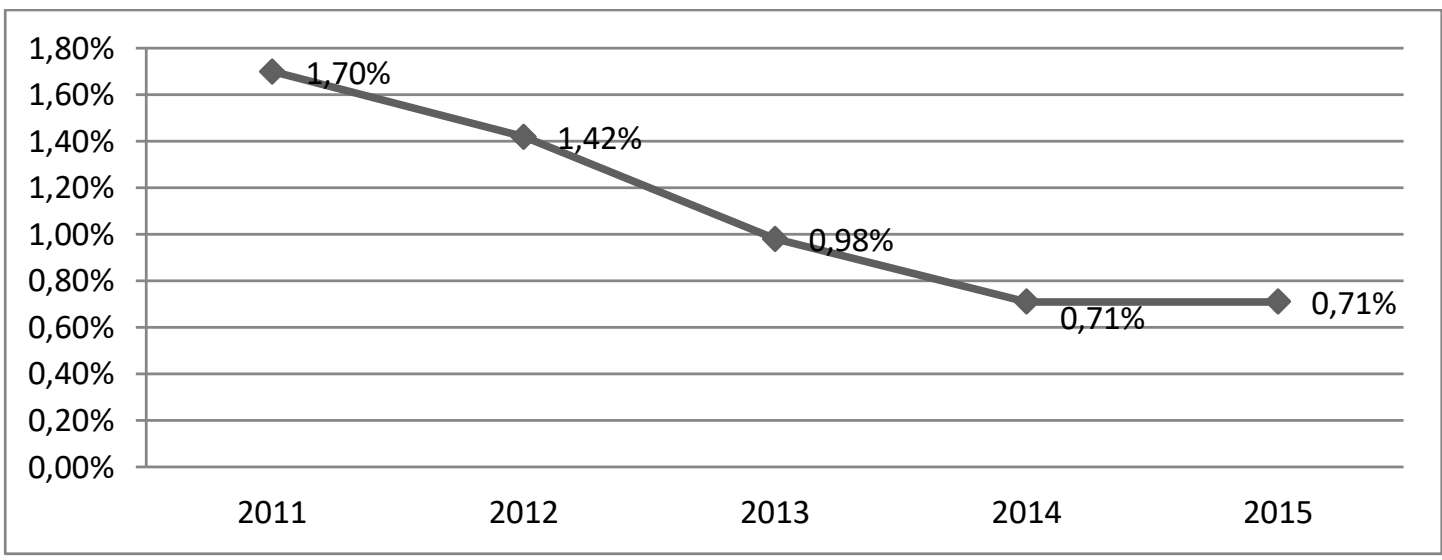

Gambar 8. Analisis Trend Rasio Pengembalian Ekuitas

Gambar 8 menunjukkan bahwa tren untuk rasio pengembalian ekuitas mengalami pernurunan dari tahun 2011 - 2015. Ini berarti bahwa kemampuan koperasi untuk mengembalikan modal sendiri masih rendah. Hasil penelitian ini sejalan dengan penelitian Mutmainnah, N dan Wardhani, R (2013).

\section{Analisis Trend Rasio Perputaran Persediaan (Inventory Turnover)}

Hasil perhitungan analisis tren untuk rasio perputaran persediaan tampak pada Gambar 9 berikut:

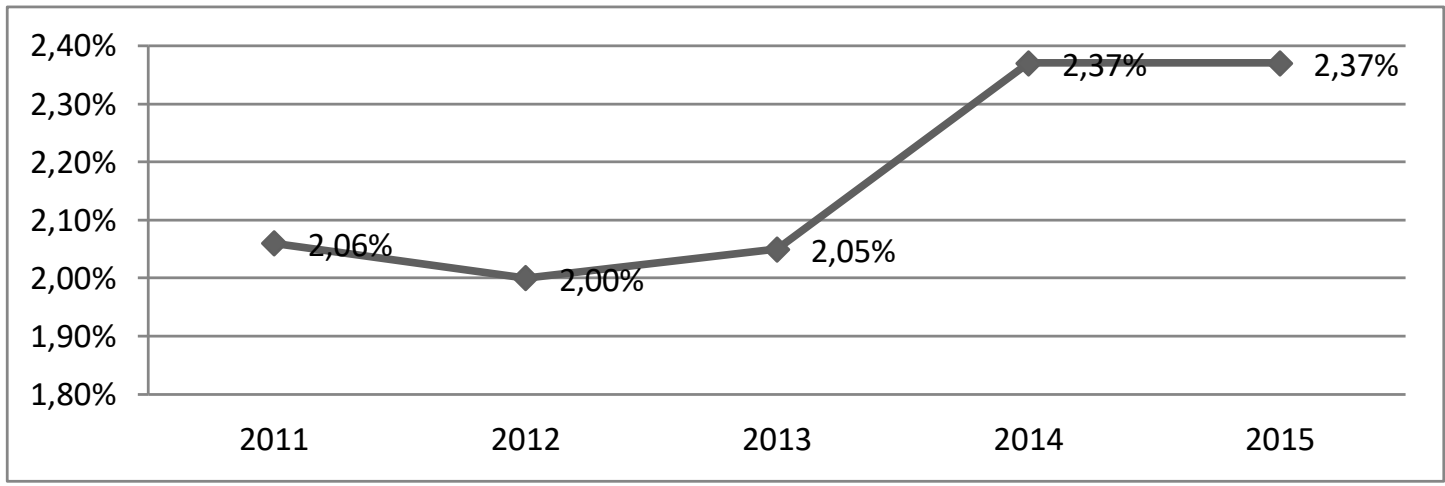

Gambar 9. Analisis Trend Rasio Perputaran Persediaan

Gambar 9 menunjukkan bahwa tren untuk rasio perputaran persediaan dari tahun 2011-2015 mengalami kenaikan, ini berarti bahwa perputaran persediaan yang 
dimiliki oleh koperasi berjalan dengan lancar. Hasil penelitian ini sejalan dengan penelitian Mutmainnah, N dan Wardhani, R (2013).

Analisis Trend Rasio Rata-Rata Pengumpulan Piutang (Day's Sales Outstanding)

Hasil perhitungan analisis tren untuk rasio rata-rata perputaran piutamng tampak pada Gambar 10 berikut:

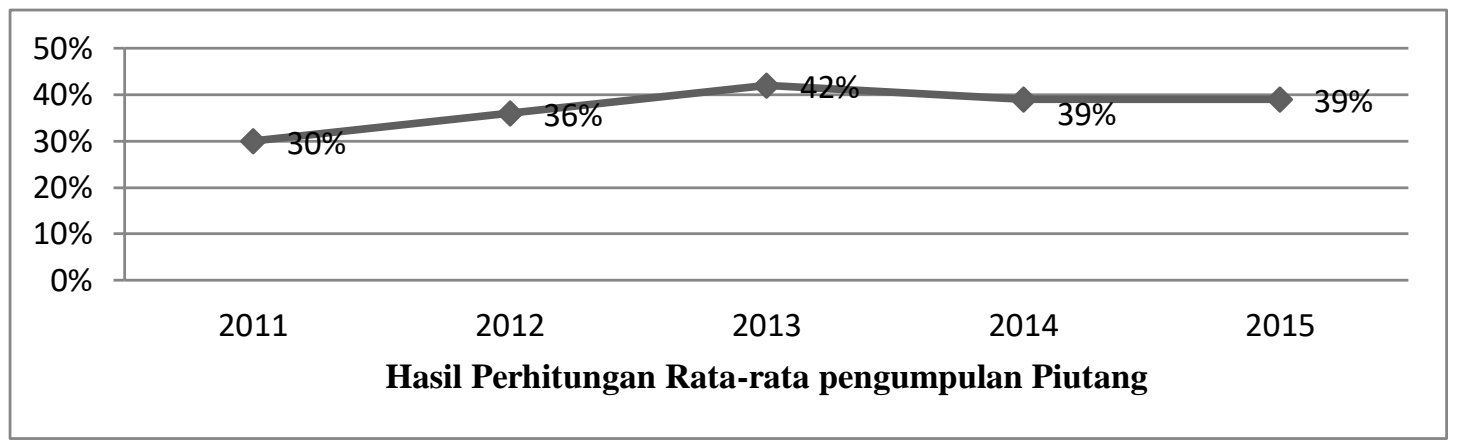

\section{Gambar 10. Analisis Trend Rasio Rata-Rata Pengumpulan Piutang}

Gambar 10 menunjukkan bahwa tren untuk rasio rata-rata piutang dari tahun 2011-2015 mengalami kenaikan. Ini menunjukkan bahwa periode pengumpulan piutang dari tahun ke tahun semakin membutuhkan waktu yang lama. Kondisi ini dapat menyebabkan koperasi in efisien. Dengan waktu yang semakin lama, maka biaya yang dikeluarkan juga semakin besar. Hasil penelitian ini tidak sejalan dengan penelitian Mutmainnah, N dan Wardhani, R (2013).

\section{Analisis Trend Rasio Perputaran Total Aset (Total Asset Turnover)}

Hasil perhitungan analisis tren untuk rasio perputaran total asset dari tahun 2011-2015 tampak pada Gambar 11 berikut:

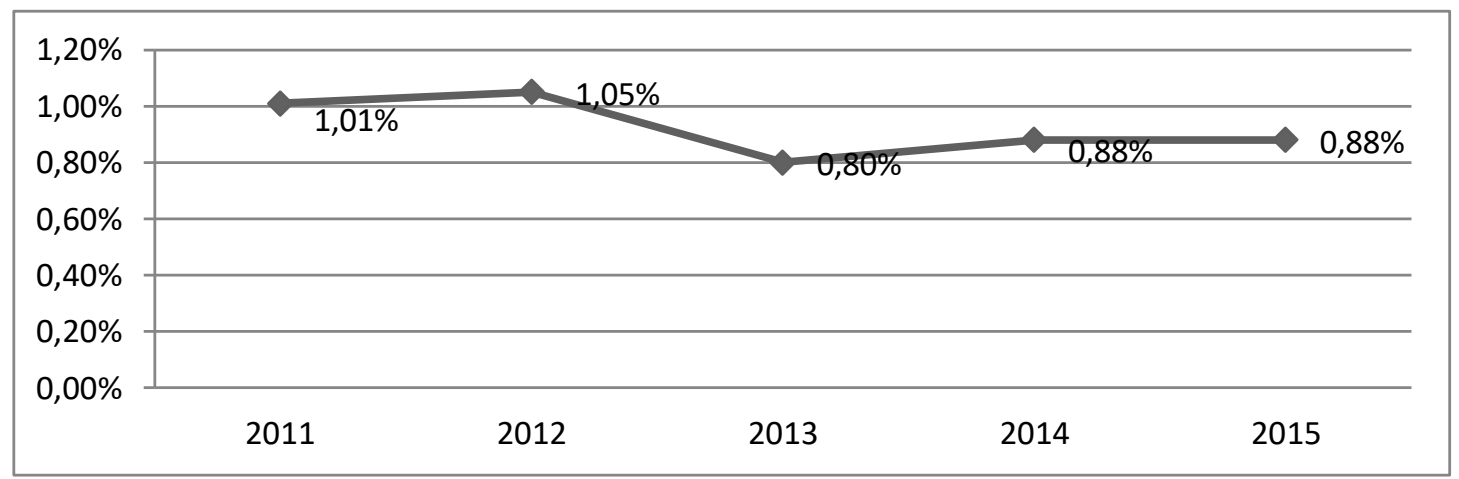

Gambar 11. Analisis Trend Rasio Perputaran Total Asset

Gambar 11 menunjukkan bahwa analisis tren untuk rasio perputaran total asset dari tahun 2011 - 2015 adalah menurun. Ini berarti bahwa perusahaan/koperasi 
tidak efektif. Hasil penelitian ini sejalan dengan penelitian Mutmainnah, $\mathrm{N}$ dan Wardhani, R (2013).

\section{Analisis Common Size}

Hasil perhitungan analisis common size tampak pada Tabel 2 berikut:

Tabel 2.

Hasil Perhitungan Analisis Common Size

\begin{tabular}{|c|c|c|c|c|c|}
\hline Pos-Pos & 2011 & 2012 & 2013 & 2014 & 2015 \\
\hline \multicolumn{6}{|l|}{ Aktiva } \\
\hline Kas & $1,93 \%$ & $1,79 \%$ & $0,79 \%$ & $0,08 \%$ & $0,08 \%$ \\
\hline Piutang & $91,38 \%$ & $91,92 \%$ & $96,17 \%$ & $96,95 \%$ & $96,95 \%$ \\
\hline Beban dibayar dimuka & $3,44 \%$ & $32,83 \%$ & $1,30 \%$ & $1,29 \%$ & $1,29 \%$ \\
\hline Perlengkapan Kantor & $4,21 \%$ & $3,79 \%$ & $2,64 \%$ & $2,66 \%$ & $2,66 \%$ \\
\hline Akumulasi Perlengkapan Kantor & $0,98 \%$ & $0,80 \%$ & $9,93 \%$ & $1,00 \%$ & $1,00 \%$ \\
\hline Total Aktiva & $100 \%$ & $100 \%$ & $100 \%$ & $100 \%$ & $100 \%$ \\
\hline \multicolumn{6}{|l|}{ Kewajiban } \\
\hline Hutang Bank & $70,29 \%$ & $65,66 \%$ & $644,2 \%$ & $649,1 \%$ & $649,1 \%$ \\
\hline Hutang Pajak & $0,07 \%$ & $0,06 \%$ & $0,49 \%$ & $0,30 \%$ & $0,30 \%$ \\
\hline \multicolumn{6}{|l|}{ Modal } \\
\hline Simpanan Pokok & $3,51 \%$ & $0,32 \%$ & $2,30 \%$ & $0,23 \%$ & $0,23 \%$ \\
\hline Simpanan Wajib & $0,59 \%$ & $0,55 \%$ & $0,39 \%$ & $0,39 \%$ & $0,39 \%$ \\
\hline Donasi & $0,70 \%$ & $0,06 \%$ & $0,04 \%$ & $0,04 \%$ & $0,04 \%$ \\
\hline Penyertaan & $28,11 \%$ & $328,3 \%$ & $34,51 \%$ & $34,09 \%$ & $34,09 \%$ \\
\hline SHU berjalan & $0,48 \%$ & $0,48 \%$ & $0,34 \%$ & $0,25 \%$ & $0,25 \%$ \\
\hline Total Kewajiban & $100 \%$ & $100 \%$ & $100 \%$ & $100 \%$ & $100 \%$ \\
\hline
\end{tabular}

Sumber: Data Sekunder diolah, 2017

Tabel 2 menunjukkan bahwa persentase aktiva lancar tertinggi pada tahun 2014 dan 2015 yaitu sebesar 97,03\% dari total aktivanya, dan terendah pada tahun 2011 sebesar 93,31\% dari total aktivanya dengan kontribusi pos pinjaman yang diberikan (piutang) memberikan angka terbesar. Aktiva lancar terdiri dari kas dan piutang. Nilai aktiva tetap menunjukkan persentase tertinggi pada tahun 2012 sebesar 37,38\% dari total aktivanya, dan terendah pada tahun 2014 sebesar 4,95\% dari total aktivanya. Pada passiva, persentase kewajiban tertinggi yaitu pada tahun 2015 sebesar 649,4\% dan persentase terendah pada tahun 2012 yaitu sebesar 65,66\%. Kewajiban terdiri dari hutang bank dan hutang pajak. Kekayaan bersih tertinggi pada tahun 2012 yaitu sebesar $329,71 \%$ yang terdiri dari Simpanan Pokok, Simpanan Wajib, Donasi, Penyertaan SHU Tahun Berjalan. Sedangkan terendah tahun 2014 yaitu sebesar $35 \%$. 


\section{SIMPULAN DAN SARAN}

\section{Simpulan}

Hasil perhitungan analisis rasio keuangan yang digunakan untuk mengukur kinerja keuangan koperasi dapat disimpulkan bahwa untuk Current Ratio dan Quick Ratio dapat dikatakan bahwa koperasi dalam kondisi sehat, karena memiliki nilai di atas $20 \%$, sedangkan untuk cash ratio, koperasi dikatakan dalam kondisi tidak sehat, karena memiliki nilai rasio dibawah $20 \%$. Rasio profitabilitas menunjukkan bahwa ratio ROI dan ROE memiliki nilai dibawah 20\%, ini berarti bahwa kondisi koperasi tidak sehat. Rasio solvabilitas menunjukkan bahwa TDER dan TDAR memiliki nilai rasio 75\%, ini berarti kondisi keuangan koperasi dalam kondisi sehat. Rasio aktifitas menunjukkan bahwa ketiga rasio yaitu rata-rata pengumpulan piutan, perputaran persediaan dan perputaran total aset memiliki nilai 0\%, ini berarti bahwa kondisi keuangan koperasi tidak sehat.

Hasil perhitungan dengan menggunakan analisis trend menunjukkan bahwa ada kecenderungan yang naik dan turun untuk seluruh rasio yang digunakan dalam penelitian ini. Ini menunjukkan bahwa kondisi kinerja keuangan koperasi dengan menggunakan analisis tren menunjukkan kondisi yang sehat, kecuali untuk perputaran total aset yang menunjukkan tidak efektif.

Hasil perhitungan dengan menggunakan analisis Common Size bahwa kondisi kinerja keuangan perusahaan masih perlu dilakukan pembenahan, karena dari analisis ini memberikan hasil yang masih sangat kecil.

\section{Saran}

Saran yang diberikan kepada koperasi dari hasil penelitian ini antara lain: 1) Manajemen koperasi perlu dilakukan perbaikan/pembenahan, 2) Bagian pemegang keuangan perlu diberikan pelatihan untuk melakukan pencatatan dan pembukuan yang sesuai dengan Standar Akuntansi Indonesia, 3) Pengelolaan koperasi perlu ditingkatkan khususnya di bidang profesionalism. 4) Diperlukan untuk melakukan diversifikasi produk, agar koperasi dapat mengembangkan usahanya.

\section{DAFTAR PUSTAKA}

Adha, W., Rahmawati, V., dan Al Azhar, A. 2014. Pengaruh Akuntabilitas, Ketidakpastian Lingkungan, dan Komitmen Pimpinan terhadap Penerapan 
Transparansi Pelaporan Keuangan (Studi Empiris pada SKPD Kota Dumai). Jurnal JOM FEKON, 1 (2) Oktober, hal. 1-15.

Anoraga, Pandji dan Ninik Widiyanti. 2007. Dinamika Koperasi. Jakarta: Rineks Cipta dan Bina Adiaksara.

Arman, Moh., Wayan Cipta, dan I Wayan Suwendra.2015. Pengaruh Kecukupan Modal dan Tingkat Penyaluran Kredit terhadap Laba pada Lembaga Perkreditan Desa. $e$ journal Bisma Universitas Pendidikan Ganesha. Volume 3 Tahun 2015.

Budiarti, R.E. 2013. Analisis Kinerja Keuangan Pada Koperasi Serba Usaha "Ida"Jemberperiode 2010-2012. Skripsi. Universitas Jember: Fakultas Ekonomi.

Fahmi, Irham. 2014. Analisis Laporan Keuangan. Bandung: Alfabeta.

Fatmawati, Mila. 2012. Penggunaan The Zmijewski Model, The Altman Model, dan The Springate Model Sebagai Prediktor Delisting. Jurnal Keuangan dan Perbankan, Vol.16, No.1, 56-65.

Farid dan Siswanto, 2011, Analisis Laporan Kuangan, Jakarta: Bumi Aksara

Fayol,Hendry.2013.Pengantar Administrasi dan fungsifungsimanajemen.http://Pengantar Administrasi $\quad-$ dan fungsi-fungsi manajemen.html. Diakses tanggal 12 Februari 2017.

Harahap, Sofyan Syafri. 2009. Teori Kritis Laporan Keuangan. Jakarta: Bumi Aksara

Ikatan Akuntansi Indonesia. 2009. Standar Akuntansi Keuangan, PSAK No. 1 : Penyajian Laporan keuangan. Jakarta : Salemba Empat.

I M. Sarjana, K. Budi Susrusa , Dwi Putra Darmawan. 2013. Analisis Kinerja Keuangan pada Koperasi Serba Usaha di Kabupaten Buleleng. https://docplayer.info/40940220-Analisis-kinerja-keuangan-pada-koperasi-serbausaha-di-kabupaten-buleleng.html. Diakses pada tanggal 10 Januari 2017.

J Drew, M Kortt, B Dollery. 2015. What determines efficiency in local government? A DEA analysis of NSW local government. Economic Papers: A journal of applied economics and policy 34 (4), 243-256.

Jumingan. 2006. Analisis Laporan Keuangan. Jakarta : PT. Bumi Aksara

Maria, D. 2015. Analisis Pengaruh Rasio Keuangan Terhadap Perubahan Bond Rating Di Indonesia (Analysis Influence of Finance Ratio to Change of Bond Ratingin Indonesia). . Vol. 6 (2), 115-127.

M Shobihin, SS Dwiningwarni, Supriyadi. 2019. Analisis Laporan Keuangan Untuk Menilai Kinerja Keuangan Pt. Astra Agro Lestari Tbk. eBA Journal: Journal of Economic, Bussines and Accounting. Vol. 5 (2), 75-88.

Moeljadi. 2006. Manajemen Keuangan-Pendekat-an Kuantitatif dan Kualitatif, Jilid 1, Edisi Pertama, Bayumedia Publishing.

Munawir, S. 2012. Analisis Informasi Keuangan, Liberty, Yogyakarta.

Mutmainnah, N dan Wardhani, R. 2013. Analisis Dampak Kualitas Komite Audit Terhadap Kualitas Laporan Keuangan Perusahaan Dengan Kualitas Audit Sebagai Variabel Moderasi. Jurnal Akuntansi dan Keuangan Indonesia, Vol. 10, No. 2, hal $147-170$.

SS Dwiningwarni, J Suharsono, DY Safitri. 2019. Pengunaaan Analisis Rasio dalam Pengukuran Kinerja Keuangan Perusahaan pada PT. Gudang Garam Tbk. Jurnal Riset Inspirasi Manajemen dan Kewirausahaan. Vol. 3 (1), 43-48.

Subramanyam, KR dan John, J. Wild, 2010. Analisis Laporan Keuangan, Buku Satu, Edisi Sepuluh, Salemba Empat, Jakarta. 